\title{
HUBUNGAN FAKTOR INTERNAL PACAR DENGAN KEKERASAN DALAM PACARAN
}

\author{
Ivanna J Manoppo \\ Fakultas Keperawatan, Universitas Klabat, Airmadidi, Minahasa Utara, 95371 \\ i.manoppo@unklab.ac.id
}

\begin{abstract}
Many women are victims of violence by their boyfriends. The act of violence can be in the form of being overly coercive and controlling their partner. This is due to the influence of consuming alcohol. The age of Boyfriend is also associated with premature sexual violence and unwanted sexual activity in adolescents. The purpose of this study was to determine the relationship between factors internal of boyfriends and violence in dating. The research method was observational analytic with cross sectional approach. The sampling technique was used purposive, with a sample of 99 respondents. The result of the study showed that include :. There is no relationship between internal factors of boyfriends when viewed from age with a value of $\mathrm{p}=0.145<0.05$. There is a very significant positive relationship with factor internal of boyfriend when viewed from the use of alcohol with a value of $p=0.00$ and a moderate correlation value. Recommendations for future research can be examined on a larger population and sample to obtain the accuracy of data, and can examine other factors such as the length of dating relationships with the incidence of dating violence.
\end{abstract}

Keywords: Factors internal of boyfriend (age and alcohol), violence in dating.

\begin{abstract}
Abstrak
Banyak perempuan yang menjadi korban tindak kekerasan oleh pacar mereka. Tindakan kekerasannya bisa jadi dalam bentuk sikap memaksa dan mengontrol pasangannya yang terlalu berlebihan. Hal ini disebabkan karena pengaruh saat mengkonsumsi alkohol. Usia pacar juga dikaitkan dengan kekerasan seksual dini dan aktivitas seksual yang tidak diinginkan pada anak remaja. Tujuan penelitian ini adalah untuk mengetahui hubungan faktor internal pacar dengan kekerasan dalam pacaran. Jenis penelitian observasional menggunakan pendekatan secara deskriptif analitik, serta desain cross sectional. Teknik sampling digunakan purposive, dengan sampel 99 responden. Hasil penelitian menunjukkan bahwa Tidak ada hubungan faktor internal pacar jika ditinjau dari usia dengan nilai $\mathrm{p}=0.145<0.05$. Ada hubungan positif yang sangat signifikan faktor internal pacar jika ditinjau dari penggunaan alkohol dengan kekerasan dalam pacaran dengan nilai $\mathrm{p}=0.00$ serta nilai korelasi yang moderat. Rekomendasi bagi penelitian selanjutnya, dapat meneliti pada populasi dan sampel yang lebih besar untuk mendapatkan keakuratan data, serta dapat meneliti faktor lain seperti lamanya hubungan pacaran dengan kejadian kekerasan dalam pacaran
\end{abstract}

Kata Kunci: Faktor internal pacar (usia dan alkohol), kekerasan dalam pacaran. 


\section{PENDAHULUAN}

\begin{abstract}
Rutherford (2017) mendefinisikan kekerasan menurut WHO adalah penggunaan kekuatan atau kekuatan fisik yang disengaja, mengancam atau, melawan seseorang, orang lain, atau melawan suatu kelompok atau komunitas, yang menghasilkan atau mengakibatkan cedera, kematian, membahayakan psikologis, dan gangguan perkembangan. Kemudian ditambahkan definisi tentang kekerasan terhadap perempuan yaitu setiap tindakan kekerasan berbasis gender yang menghasilkan, atau memiliki kemungkinan besar mengakibatkan kerugian atau penderitaan secara fisik, seksual, atau psikologis bagi perempuan, termasuk ancaman, paksaan atau perampasan kebebasan secara sewenang-wenang, baik yang terjadi di depan umum atau kehidupan pribadi.
\end{abstract}

Rutherford (2017) menyatakan di seluruh dunia, setiap 1 hari sekitar 4.500 orang akan mati dengan kekerasan: Setengah dari ini berasal dari luka yang diderita sendiri, sepertiga akibat dibunuh, dan seperlima terbunuh dalam perang. Sekitar $90 \%$ dari orang-orang ini tinggal di negara berpenghasilan rendah atau menengah. Tingkat kematian akibat kekerasan bervariasi secara signifikan antara negara-negara, dengan tingkat tertinggi di wilayah WHO di Amerika. Perkiraan prevalensi seumur hidup dari beberapa bentuk kekerasan, misalnya bahwa $10-50 \%$ perempuan mengalami kekerasan fisik dari pasangan intim di masa hidup.

Kekerasan dapat terjadi kepada siapa saja dan di mana saja. Berbaga jenis kekerasan yang sudah diketahui saat ini di antaranya kekerasan terhadap anak, kekerasan terhadap pasangan intim, kekerasan pada teman kerja, kekerasan pada pasien dan juga terhadap tenaga kesehatan dan tidak menutup kemungkinan kekerasan dalam pacaran yang sering menjadi tren topik saat ini
Menurut Hasan (2013) dalam jurnal perempuan kekerasan dalam suatu hubungan bukan hanya melanda pasangan yang sudah menikah saja atau disebut kekerasan dalam rumah tangga (KDRT). Saat ini banyak perempuan yang menjadi korban tindak kekerasan oleh pacar mereka. Tindakan kekerasannya bisa jadi dalam bentuk sikap memaksa dan mengontrol pasangannya yang terlalu berlebihan.

Kekerasan dalam pacaran menempati urutan kedua dalam kasus kekerasan terhadap perempuan setelah kekerasan dalam rumah tangga (KDRT), Data dari Komnas Perempuan sejak tahun 2010 terjadi 1.000 kasus kekerasan dalam pacaran.

Menurut Brem, Florimbio, Grigorian, Elmquist, Clevenger, dan Stuart (2018) penelitian saat ini mendefinisikan kekerasan dalam pacaran sebagai ancaman atau tindak kekerasan terhadap pasangan dalam pacaran saat ini atau sebelumnya. Kekerasan dalam bentuk fisik didefinisikan sebagai penggunaan kekuatan fisik yang disengaja, terhadap korban yang mengakibatkan cedera fisik atau kematian. Tindakan tersebut dapat termasuk menampar, meninju, atau mencekik. Kekerasan Psikologis dalam pacaran didefinisikan sebagai tindakan lisan atau perilaku yang memiliki niat untuk menyalahkan, mempermalukan, mendominasi, mengintimidasi, atau mengancam pasangan seseorang. Ini dapat mencakup banyak tindakan yang mungkin seperti ancaman verbal atau isolasi pasangan seseorang dari keluarga dan teman-teman. Kekerasan dalam bentuk pemaksaan seksual dalam hubungan pacaran didefinisikan sebagai segala tindakan seksual yang dilakukan di mana persetujuan tidak diberikan secara bebas atau tidak dapat diberikan seperti dalam kasus keracunan, ketidaksadaran, atau kecacatan. Menguntit juga didefinisikan sebagai pelecehan atau ancaman yang tidak diinginkan yang terjadi dalam suatu hubungan dan menyebabkan ketakutan atau masalah keselamatan bagi para korban. 
Nurherwati (2018) memberikan gambaran pada tahun 2017 angka kekerasan dalam pacaran berada pada posisi ketiga setelah kekerasan terhadap istri dan kekerasan pada anak. Bentuk kekerasan yang paling tinggi dalam Kekerasan Dalam Pacaran adalah kekerasan fisik dan sosial. Kekerasan dalam pacaran berawal dari politisasi cinta yang ada dalam relasi pacaran, perempuan yang telah dikonstruksi untuk berada di posisi memberi seringkali direspon oleh pasangannya yang menggunakan politik kekuasaan. Nurherwati menyampaikan bahwa sebanyak $85 \%$ kekerasan dalam pacaran dapat berlanjut pada kekerasan dalam rumah tangga (KDRT).

Jaffe, Fairbairn, dan Sapardanis (2018) Kekerasan dalam pacaran semakin diakui sebagai masalah kesehatan masyarakat yang menyebabkan kerugian baik secara psikologis dan fisik yang serius bagi para korban. Menurut Survei Perilaku Risiko Remaja Nasional tahun 2013, sekitar 10\% siswa sekolah menengah telah mengalami kekerasan fisik dalam hubungan pacaran, dan $10 \%$ juga melaporkan kekerasan seksual. Di antara mahasiswi Kanada, 79\% melaporkan kekerasan secara psikologis dari pacar mereka, 27\% telah mengalami kekerasan seksual, dan 22\% melaporkan kekerasan fisik, Dalam kasus-kasus ekstrem, kekerasan dalam pacaran mengakibatkan kematian dalam bentuk pembunuhan atau bunuh diri. Kelompok remaja yang menjadi risiko tertinggi adalah $13-18$ tahun dan orang dewasa 15- 24 tahun

Komnas Perempuan (2018) dalam catatan tahunan Komisi Nasional Anti Kekerasan Terhadap Perempuan/KTP (Komnas Perempuan) memberikan data hampir di seluruh provinsi Indonesia, di mana pada tahun 2017 kasus KTP melebihi jumlahnya daripada tahun sebelumnya yaitu sebanyak 348.446 kasus. Data ini menemukan untuk kasus kekerasan terhadap isteri (KTI) menempati urutan pertama dan diikuti oleh kasus kekerasan dalam pacaran (KDP). $\begin{array}{crr}\text { Menurut } & \text { Kementerian } \\ \text { Pemberdayaan } & \text { Perempuan dan }\end{array}$

Perlindungan Anak RI (2018) didapati kekerasan dialami oleh perempuan yang belum menikah dengan jumlah $42.7 \%$. Perempuan yang mengalami kekerasan seksual berjumlah $34.4 \%$ dan yang mengalami kekerasan dalam bentuk seksual sebanyak $19.6 \%$, dan didapati pelaku kekerasan berjumlah 10.847 di mana 2.090 pelakunya adalah pacar dari korban kekerasan

Kasus kekerasan pada anak dan perempuan di SULUT juga terjadi peningkatan setiap tahun menurut Martinus (2018) Menurut catatan Dinas Pemberdayaan Perempuan dan Perlindungan Anak (P3A) Sulawesi Utara pada tahun 2016 ada sebanyak 135 kasus kemudian bertambah menjadi 137 kasus dan pada tahun 2018 data terakhir bulan Oktober didapati sebanyak 150 kasus

Hasan (2013) menyatakan penyebab tingginya angka kekerasan dalam pacaran terjadi akibat banyaknya perempuan yang tidak paham bentuk kekerasan fisik maupun psikis dalam suatu hubungan. Hal ini yang membuat remaja perempuan tidak menyadari jika sudah menjadi korban kekerasan oleh pacar mereka, dalam kasus ini remaja yang paling rentan menjadi korban kekerasan. Sebab di usia itu, gairah sedang meningkat dan dapat mendorong seseorang untuk mengartikan kasih sayang ke hal yang salah. Pembiaran hubungan yang tidak sehat, bahkan sampai melakukan tindak kekerasan, dapat menimbulkan risiko fatal

Rutherford (2017) Berbagai jenis kekerasan memiliki faktor risiko yang berbeda, yaitu termasuk penyalahgunaan alkohol, penggunaan senjata, kemiskinan dan norma sosial yang mendukung terjadinya kekerasan. Lebih lanjut dikatakan bahwa ada beberapa obat, termasuk alkohol, digunakan untuk memfasilitasi terjadinya kekerasan seksual. Darman (2006) menyebutkan bahwa remaja memiliki risiko besar terhadap pemakaian narkoba, hal ini mengakibatkan 
perubahan peran yang tidak sesuai dengan tumbuh kembang anak tersebut. Penggunaan narkoba pada anak menyebabkan ada perilaku menyimpang dalam seksual, prilaku anti sosial dalam usia dini.

Rosdiana (2018) menyatakan bahwa banyak kejahatan yang dilakukan di antaranya kekerasan, hal ini disebabkan karena pengaruh saat mengkonsumsi alcohol/narkoba. Narkoba secara umum dapat mengubah psikologis seseorang, di mana dapat membuat pikiran, persepsi dan suasana hati berubah-ubah

Menurut Brem, Florimbio, Grigorian, Elmquist, Clevenger \& Stuar (2018) faktor risiko untuk kekerasan dalam pacaran adalah penggunaan zat (alkohol, narkoba). Sebuah studi menunjukkan bahwa penggunaan alkohol dalam jumlah besar secara temporer meningkatkan risiko kekerasan dalam pacaran di kalangan pria. Selain itu, dalam tinjauan sistematis literatur yang meneliti hubungan antara penggunaan narkoba dan kekerasan dalam pacaran, melaporkan hubungan yang signifikan antara penggunaan narkoba dan kekerasan dalam pacaran untuk pria dan wanita di perguruan tinggi

Marin, Coyle, Carvajal dan Kirby (2000) menyimpulkan bahwa usia pacar memiliki hubungan yang signifikan terjadinya kekeraan di mana memiliki pacar yang lebih tua dikaitkan dengan kejadian seksual dini dan aktivitas seksual yang tidak diinginkan pada populasi anak remaja.

Lebih lanjut Marin, Coyle, Carvajal dan Kirby (2008) menyatakan ada sejumlah alasan mengapa pasangan yang lebih tua mungkin menggunakan kekuatan tertentu dengan remaja yang lebih muda. Pasangan yang lebih tua cenderung lebih menarik bagi remaja muda karena sumber daya, kedewasaan, dan status yang mereka bawa ke hubungan Pasangan yang lebih tua lebih mungkin untuk melakukan hubungan seksual daripada yang lebih muda, dan beberapa penelitian menunjukkan bahwa pria yang lebih tua dapat mencari pasangan yang lebih muda justru karenalebih mampu mengendalikan orang tersebut dan interaksi mereka. Orang-orang dengan pacar yang lebih tua juga melaporkan lebih banyak kejadian seksual yang tidak diinginkan daripada remaja yang tiddak memiliki pacar, atau memiliki pacar dengan usia yang sama.

White (2013) menyatakan bahwa perilaku atau karakter dari para pemuda dapat dilihat dari pegaulan seseorang. Pengaruh pergaulan merupakan salah satu faktor pemicu para pemuda untuk melakukan sesuatu, di mana ada mata rantai rahasia yang mengikat jiwa-jiwa secara bersama-sama pada saat seseorang menyambut hati orang lain. Di mana seseorang akan menangkap ide-ide, perasaan dan semangat orang lain. Pergaulan ini dapat menghasilkan sesuatu yang baik (berkat) atau kutuk. Jadi perihal memilih teman adalah sesuatu yang harus dipikirkan dengan baik, karena dengan menunjukkan siapa teman seorang pemuda akan bisa menunjukkan karakter yang dimilikinya. Alkitab juga menjelaskan dalam Amsal 18: 24 bahwa ada teman yang mendatangkan kecelakaan, tetapi ada juga sahabat yang lebih karib daripada seorang saudara.

Berdasarkan latar belakang dan tinjaun teoritis yang sudah dipaparkan, tujuan penelitian ini untuk mengidentifikasi bentuk-bentuk kekerasan dalam pacaran yang dialami remaja perempuan. Hasilnya dapat memberikan masukan kepada fakultas untuk memberikan topik-topik kekerasan yang terkait pada kurikulum yang ada serta dapat menyediakan fasilitas konseling bagi korban yang beresiko ataupun yang sudah mengalami kekerasan dalam pacaran

\section{Perumusan Masalah}

1. Bagaimana gambaran bentuk kekerasan dalam pacaran pada Mahasiswi di Unklab?

2. Bagaimana gambaran faktor internal pacar (usia dan penggunaan alcohol) pada mahasiswi di Unklab? 
3. Apakah ada hubungan yang signifikan antara faktor internal pacar (usia) dengan kekerasan dalam pacaran pada mahasiswi di Unklab?

4. Apakah ada hubungan yang signifikan antara faktor internal (penggunaan alkohol) dengan kekerasan dalam pacaran pada mahasiswi di Unklab

\begin{tabular}{l}
\multicolumn{1}{l}{ Kerangka Konsep } \\
\multicolumn{1}{|c|}{ Independen } \\
\hline \multicolumn{1}{|l|}{ Faktor Internal } \\
Pacar: \\
1. Usia \\
2. Penggunaan \\
alkohol
\end{tabular}

\section{Hipotesis Penelitian}

Ha1: Ada hubungan faktor internal pacar (usia) dengan kekerasan dalam pacaran Ha2: Ada hubungan faktor internal pacar (penggunaan alkobol) dengan kekerasan dalam pacaran

\section{METODE PENELITIAN}

Penelitian ini menggunakan pendekatan secara deskriptif analitik, dengan melihat hubungan satu variabel dengan yang lain (korelasi) dan desain cross sectional.

\section{Variabel Penelitian}

Dalam penelitian ini terdapat 2 variabel yakni variabel bebas dan variabel terikat. Variabel bebas (X) usia dan penggunaan alkohol, sedangkan variabel terikat (Y) kekerasan dalam pacaran.

\section{Rumus Penelitian}

Menjawab pernyataan masalah pertama sampai kedua: Bagaimana gambaran bentuk kekerasan dalam pacaran pada mahasiswi keperawatan di Universitas Klabat?;Bagaimana gambaran faktor internal (usia pacar dan penggunaan alkohol) pada mahasiswi keperawatan di Universitas Klabat? menggunakan rumus mean dan frekuensi.

Untuk menjawab pernyataan masalah ketiga dan keempat; Apakah ada hubungan faktor internal pacar (usia) dengan kekerasan dalam pacaran? Dan apakah ada hubungan factor internal pacar (penggunaan alkohol dengan kekerasan dalam pacaran pada mahasiswi di Universitas Klabat? Menggunakan rumus Pearson correlation. Tingkat kesalahan pada penelitian ini adalah $5 \%$.

\section{Subjek Partisipan dalam Penelitian}

Subjek partisipan dalam penelitian ini adalah mahasiswi keperawatan Unklab.

\section{Populasi dan sampel}

Populasi dalam penelitian ini adalah semua mahasiswi keperawatan. Teknik pengambilan sampel yang digunakan secara purposive, dengan kriteria inklusi adalah mahasiswi tingkat 3 \& 4 yang memiliki pengalaman pacaran sebelumnya dan sedang pacaran, dan dapat bekerja sama serta memberikan persetujuan. Batasan penelitian adalah mahasiswi keperawatan yang pernah dan sedang menjalin hubungan dengan teman laki-laki minimal dalam jangka waktu 1 bulan.

\section{Instrumen Penelitian}

Instrumen yang digunakan dalam penelitian ini adalah kuesioner yang terdiri dari 3 bagian bagian yaitu, kuesioner usia, penggunaan alcohol serta kuesioner kekerasan dalam pacaran. Kuesioner penggunaan alkohol dari Espelage, Davis, Basile, Rostad, dan Leemis (2018) dan kuesioner usia dari Marin, Coyle, Gomez, Carvajal \& Kirby (2000). Untuk kuesioner penggunaan alkohol dan narkoba serta usia akan dilakukan uji validas secara expert. Kuesioner kekerasan dalam pacaran dari Diaz, Herrero, Franco, Molleda,Quesada, Perez (2016) dengan nilai reliabilitas 0.85 yang sudah dilakukan validasi expert. 
a. Kekerasan dalam pacaran : Ada 20 pernyataan yang terbagi atas 5 bagian yang pertama kekerasan dalam bentuk penghinaan, yang kedua dalam bentuk pemaksaan, yang ketiga kekerasan secara seksual, yang keempat kekerasan dalam bentuk fisik dan kelima dari segi sikap atau pendirian. Kuesioner dalam bentuk skala likert diberi nilai skor 0-4 untuk setiap pernyataan. Adapun kriteria penilaian sebagai berikut:

Skor 4 diberikan ketika responden menjawab 'selalu', skor 3 untuk jawaban sering sekali, skor 2 untuk jawaban sering, kemudian skor 1 untuk jawaban jarang dan skor 0 untuk jawaban tidak pernah.

b. Penggunaan alkohol : dibuat dalam 3 kategori yang pertama pernah menggunakan alkohol, yang kedua penggunaan alkohol saat ini (dalam sebulan terakhir) dan yang ketiga penggunaan alkohol (5 kali minum atau lebih dalam 1 bulan terakhir). Untuk pernyataan narkoba dalam bentuk ya dan tidak

c. Usia pacar: dibuat dalam 3 kategori kategori yaitu $\leq 1$ tahun dan $\geq 2$ tahun dan sama umur.

Tabel 1 Interpetasi Skala Likert Kekerasan dalam Pacaran (KDP)

\begin{tabular}{lll}
\hline $\begin{array}{l}\text { Skala respon } \\
\text { rata-rata }\end{array}$ & $\begin{array}{l}\text { KDP } \\
\text { interval }\end{array}$ \\
\hline 4 & Selalu & $3.3-4.00$ \\
3 & Sering sekali & $2.5-3.2$ \\
2 & Sering & $1.7-2.4$ \\
1 & Jarang & $0.9-1.6$ \\
0 & Tidak pernah & $0.1-0.8$ \\
\hline
\end{tabular}

\section{Teknik Pengumpulan Data}

Data primer dalam penelitian ini diperoleh melalui hasil kuesioner pada mahisiswi di Universitas Klabat Airmadidi

\section{Etika dalam Penelitian}

1. Memperoleh izin dari dekan fakultas Ilmu Keperawatan Universitas klabat

2. Lembar persetujuan

Setiap informan yang ikut dalam penelitian diberi informasi tentang maksud dan tujuan dari penelitian. Jika informan bersedia ikut dalam penelitian, maka harus menandatangani lembar persetujuan informan dan apabila menolak untuk diteliti maka peneliti tidak akan memaksa dan tetap menghormati haknya

3. Azas kerahasiaan

Informasi yang diberikan informan akan dijaga kerahasiaannya oleh peneliti dan hanya data yang sesuai dengan kebutuhan penelitian yang akan dilaporkan oleh peneliti

4. Azas manfaat

Peneliti berusaha untuk memaksimalkan manfaat dari penelitian dan meminimalkan kerugian yang timbul akibat penelitian ini

5. Azas keadilan

Semua informan yang ikut dalam penelitian ini diperlakukan secara adil dan diberikan hak yang sama

\section{HASIL}

Bab ini membahas tentang analisa data dan uji hipotesa melalui interpretasi data peneliti dengan pengolahan data menggunakan program statistik yang bertujuan menjawab rumusan masalah yang telah dijelaskan sebelumnya.

\section{Gambaran Kekerasan dalam Pacaran (KDP) pada Mahasiswi di Unklab}

Gambaran kekerasan dalam pacaran pada mahasiswi di Unklab dapat dilihat pada tabel 2 
Tabel 2. Gambaran KDP pada Mahasiswi

\begin{tabular}{|c|c|c|c|c|c|}
\hline \multicolumn{6}{|c|}{ Kategori_KDP } \\
\hline \multirow{5}{*}{ Valid } & \multicolumn{2}{|c|}{ Frequency } & Percent & $\begin{array}{c}\text { Valid } \\
\text { Percent }\end{array}$ & $\begin{array}{c}\text { Cumulative } \\
\text { Percent }\end{array}$ \\
\hline & tidak & 90 & 90.9 & 90.9 & 90.9 \\
\hline & jarang & 8 & 8.1 & 8.1 & 99.0 \\
\hline & sering & 1 & 1.0 & 1.0 & 100.0 \\
\hline & Total & 99 & 100.0 & 100.0 & \\
\hline
\end{tabular}

Tabel 2 menunjukkan gambaran kekerasan dalam pacaran pada mahasiswi di Unklab di antaranya ada sebanyak 1 orang (1.0\%) yang sering mengalami KDP, dan diikuti oleh 8 orang $(8.1 \%)$ yang jarang mengalami KDP, kemudian ada 90 orang (90.9\%) yang tidak pernah mengalami KDP. Kesimpulan pada hasil penelitian didapati bahwa sebagian besar (90.9\%) responden tidak pernah mengalami KDP.

\section{Gambaran faktor internal pacar (usia dan penggunaan alkohol) pada mahasiswi di Unklab}

Gambaran faktor internal pacar pada mahasiswi di Unklab dapat dilihat pada tabel 3 dan 4

Tabel 3. Gambaran Faktor internal pacar (usia)

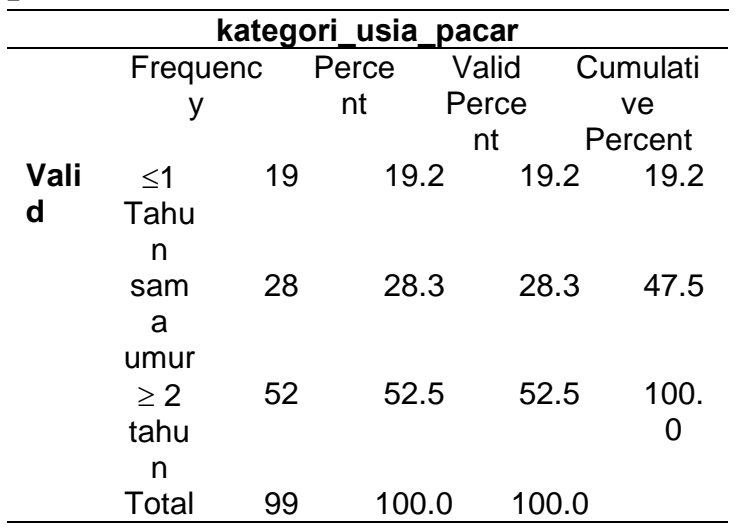

Tabel 3 menunjukkan bahwa kategori usia pacar dari responden di antaranya lebih muda 1 tahun dari responden berjumlah 19 orang (19.2\%), diikuti yang memiliki umur yang sama dengan responden berjumlah 28 orang $(28.3 \%)$, kemudian yang memiliki usia lebih tua 2 tahun dari responden sebanyak 52 orang $(52.5 \%)$. Hasil ini menunjukkan bahwa usia pacar dari responden yang terbanyak berada di usia lebih tua 2 tahun dari responden.

Tabel 4 Gambaran faktor internal pacar (penggunaan alkohol)

\begin{tabular}{|c|c|c|c|c|c|}
\hline & & Frequency & Percent & $\begin{array}{c}\text { Valid } \\
\text { Percent }\end{array}$ & $\begin{array}{c}\text { Cumulative } \\
\text { Percent }\end{array}$ \\
\hline \multirow[t]{5}{*}{ Valid } & $\begin{array}{l}\text { tidak } \\
\text { pernah }\end{array}$ & 84 & 84.8 & 84.8 & 84.8 \\
\hline & $\begin{array}{l}\text { Jarang } \\
(3 \\
\text { gelas })\end{array}$ & 6 & 6.1 & 6.1 & 90.9 \\
\hline & $\begin{array}{l}\text { Sering } \\
(6 \\
\text { gelas })\end{array}$ & 3 & 3.0 & 3.0 & 93.9 \\
\hline & $\begin{array}{l}\text { Selalu } \\
(10 \\
\text { gelas } \\
\text { atau } \\
\text { lebih) }\end{array}$ & 6 & 6.1 & 6.1 & 100.0 \\
\hline & Total & 99 & 100.0 & 100.0 & \\
\hline
\end{tabular}

Tabel 4 menunjukkan gambaran faktor internal pacar dalam penggunaan alkohol di antaranya yang sering menggunakan alkohol (9 gelas) sebanyak 3 orang, diikuti 6 orang pada kategori jarang menggunakan alkohol (3 gelas) dan selalu menggunakan

alkohol (10 gelas atau lebih) kemudian sebanyak 84 orang $(84.8 \%)$ yang memiliki pacar yang tidak pernah minum alkohol. Hasil ini menunjukkan bahwa sebagian besar pacar responden tidak pernah minum alkohol.

\section{Hubungan yang signifikan antara faktor internal pacar (usia) dengan kekerasan dalam pacaran pada mahasiswi di Unklab}

Hubungan antara faktor internal pacar dari segi usia dengan KDP pada Mahasiswi di Unklab dapat dilihat pada tabel 5 
Tabel 5 Hubungan faktor internal pacar (usia) dengan KDP

\begin{tabular}{lllrr}
\hline \multicolumn{5}{c}{ Tabel 5 Hubungan Faktor internal pacar (usia) dengan KDP) } \\
Correlations
\end{tabular}

Tabel 5 bahwa hubungan faktor internal pacar jika ditinjau dari usia menunjukkan nilai $\mathrm{p}=0.145<0.05$ yang berarti tidak ada hubungan antara faktor usia dengan terjadinya kekerasan. Hal ini menunjukkan bahwa baik usia lebih muda 1 tahun, sama usia atau > 2 tahun usia pacar dari responden dapat menjadi faktor penyebab terjadinya kekerasan. Hal ini berarti semua kategori usia pacar dapat menyebabkan terjadinya perilaku kekerasan pada wanita.

\section{Hubungan faktor internal pacar (penggunaan alkohol) dengan KDP pada Mahasiswi di Unklab}

Hubungan Faktor penggunaan alkohol dengan KDP dapat dilihat pada tabel 6

Tabel 6 Hubungan faktor internal pacar (penggunaan alkohol) dengan KDP

Correlations

\begin{tabular}{|c|c|c|c|c|}
\hline & & & $\begin{array}{c}\text { konsumsi } \\
\text { alkohol }\end{array}$ & KDP \\
\hline \multirow{6}{*}{$\begin{array}{l}\text { Spe } \\
\text { arm } \\
\text { an's } \\
\text { rho }\end{array}$} & \multirow[t]{3}{*}{$\begin{array}{l}\text { konsumsi } \\
\text { _alkohol }\end{array}$} & $\begin{array}{l}\text { Correlation } \\
\text { Coefficient }\end{array}$ & 1.000 & $.376^{* *}$ \\
\hline & & $\begin{array}{l}\text { Sig. (2- } \\
\text { tailed) }\end{array}$ & & .000 \\
\hline & & $\mathrm{N}$ & 99 & 99 \\
\hline & \multirow[t]{3}{*}{ KDP } & $\begin{array}{l}\text { Correlation } \\
\text { Coefficient }\end{array}$ & $.376^{* *}$ & 1.000 \\
\hline & & $\begin{array}{l}\text { Sig. (2- } \\
\text { tailed) }\end{array}$ & .000 & \\
\hline & & $\mathrm{N}$ & 99 & 99 \\
\hline
\end{tabular}

Tabel 6 menggambarkan hubungan faktor internal pacar (penggunaan alkohol) memiliki nilai $\mathrm{p}=0.00$ dan nilai korelasi
0.37. Dengan demikian Ha2" Ada hubungan penggunaan alkohol dengan kekerasan dalam pacaran, di terima.

\section{PEMBAHASAN}

Menurut Brem, Florimbio, Grigorian, Elmquist, Clevenger \& Stuar (2018) memberikan definisi dari kekerasan dalam pacaran dapat dibagi dalam beberapa bentuk di antaranya, fisik, psikologikal, dan seksual. kekerasan didefinisikan sebagai penggunaan kekerasan fisik yang disengaja terhadap korban yang mungkin atau tidak mengakibatkan cedera fisik atau kematian. Prevalensi kekerasan pacaran di perguruan tinggi bervariasi secara signifikan tergantung pada jenis kekerasan, definisi kekerasan dalam pacaran, dan langkahlangkah / pertanyaan yang digunakan untuk menilai kekerasan dalam pacaran di perguruan tinggi. Meskipun perbedaan dalam prevalensi, telah didokumentasikan dengan baik bahwa prevalensi kekerasan dalam pacaran merupakan masalah yang signifikan di antara populasi usia perguruan tinggi, dengan frekuensi kekerasan pacaran menjadi yang tertinggi selama usia dewasa muda Secara khusus, diperkirakan sekitar $10 \% 50 \%$ dari mahasiswa telah mengalami setidaknya satu bentuk kekerasan dalam pacaran. Pernyataan ini sama dengan hasil penelitian yang didapat bahwa ada beberapa orang yang mengalami KDP walaupun jumlahnya tidak banyak. Anantri (2015) menyebutkan Pada tahun 2012 terdapat 14 kasus, tingginya KDP di Kota Semarang salah satunya adalah seringnya pemberitaan yang ada di Media massa. Ciri khas yang sering muncul dalam kasuskasus kekerasan dalam pacaran adalah bahwa korban biasanya memang cenderung lemah, kurang percaya diri dan sangat mencintai pasangannya dan yang terjadi apabila telah melakukan tindakan kekerasan biasanya menunjukan sikap menyesal, minta maaf, dan berjanji tidak akan mengulangi tindakan kekerasan lagi, dan bersikap manis kepada pasangannya. Ariestina (2009) mengatakan bahwa kekerasan terhadap perempuan 
berhubungan dengan ketimpangan gender dan berdampak pada kesehatan dan hak asasi manusia. Di Jakarta, pada periode 2000-2002, sekitar 264 perempuan melaporkan mengalami KDP dan sekitar $11,6 \%$ kekerasan tersebut terjadi pada masa pacaran. Secara menyeluruh, satu dari sepuluh perempuan mengalami kekerasan dalam pacaran.

Martins, Gouvenia, Chaves, Lourenco, Margues, dan Santos (2014) kuesioner dating violence and wellbeing menyatakan bahwa pelaku kekerasan umumnya adalah laki-laki terhadap wanita. Penelitian ini juga menemukan bahwa korban kekerasan pada usia lebih muda mengalami penurunan kesejahteraan secara fisik, kemudian dengan meningkatnya usia korban didapati bahwa terjadi frekuensi kekerasan seksual yang lebih buruk. Marin, Coyle, Gomez, Carvajal dan Kirby (2000) menyebutkan ada sejumlah alasan mengapa pasangan yang lebih tua mungkin menggunakan kekuatan tertentu dengan remaja yang lebih muda. Pasangan yang lebih tua cenderung lebih menarik bagi remaja muda karena sumber daya, kedewasaan, dan status yang mereka bawa ke hubungan. Juga, seorang pemuda berada pada posisi sosial dan perkembangan yang tidak menguntungkan ketika berkencan dengan seseorang beberapa tahun lebih tua. Young \& Arcy (2005) menggambarkan kehadiran pasangan yang lebih tua sebagai mediator faktor risiko psikososial dan perilaku masalah remaja (termasuk aktivitas seksual dini). Marin, Coyle, Go mez, Carvajal dan Kirby (2000) menemukan bahwas siswa yang memiliki teman laki-laki atau teman perempuan 30 kali lebih mungkin melakukan sex daripada mereka yang tidak mempunyai teman lakilaki atau teman perempuan

Hasil ini bertolak belakang dengan Ariestina (2009) menemukan bahwa umumnya faktor-faktor yang berhubungan dengan kejadian KDP adalah sosiodemografi, kelemahan fisik, pengetahuan, sikap, keterpaparan terhadap informasi, konflik dalam keluarga, teman sebaya, persepsi sosial yang terdapat pada korban, sedangkan dari pelaku kekerasan ada karakteristik, penggunaan alkohol, dan penggunaan narkoba. Data observasi yang didapat adalah pacar dari responden kebanyakan bersekolah di Universitas yang memiliki aturan ketat tentang penggunaan alkohol. Selain itu juga di Universitas sering diadakan pembanguanan spiritual, tempat konseling mahasiswa, taman doa sehingga hal ini menyebabkan para mahasiswa jika mengalami masalah orang muda ataupun yang lain tidak akan memicu mereka untuk menggunakan. Namun variabel - variabel yang berhubungan bermakna hanya variabel kelemahan fisik, sikap terhadap kekerasan, konflik dalam keluarga, keterpaparan terhadap informasi, dan penggunaan alkohol oleh pacar. (taruh di hasil hubungan)

Hasil ini bertentangan dengan Seifert (2012) mengklasifikasikan faktorfaktor yang dapat memengaruhi kekerasan ke dalam tiga kelompok faktor besar, yaitu faktor demografis, individual, dan lingkungan. Dalam hal ini jumlah kekerasan semakin meningkat pada kelompok usia yang lebih tinggi, dan sangat jarang terjadi pada kelompok usia di bawah 10 tahun. Jadi prevalensi kekerasan (berlaku untuk hampir semua tindak kekerasan meningkat dengan bertambahnya usia. Jumlah tindak kekerasan tertinggi umumnya berada pada kelompok usia remaja di berbagai Negara. Javdani dkk (2019) menemukan wanita dengan teman laki-laki yang lebih tua mendapat tekanan sosial yang sangat besar dan berada dalam hubungan yang membuat mereka terpapar dengna kekerasan dalam pacaran yang membuat mereka stres dengan menunjukkan gejala-gejala eksternal.

Penelitian menunjukkan ada hubungan positif yang sangat signifikan antara penggunaan alkohol dengan KDP dan memiliki nilai korelasi yang moderat. Itu berarti semakin tinggi penggunaan alkohol maka semakin tinggi terjadinya KDP. Penelitian ini didukung dengan 
penelitian dari Espelage, Davis, Basile, Rostad dan Leemis (2017) mendapati bahwa penyalahgunaan alkohol dan obat resep muncul sebagai faktor risiko yang signifikan untuk kekerasan seksual dan kekerasan pacaran di kalangan remaja. Reyes, foshee, Bauer, dan Ennett (2014) menemukan bahwa efek penggunaan alkohol berat pada kekerasan dalam pacaran cenderung berkurang dari waktu ke waktu dan lebih kuat di musim semi daripada di semester musim gugur. Konsisten dengan hipotesis, di semua tingkatan, hubungan antara penggunaan alkohol berat dan kekerasan dalam pacaran lebih kuat untuk remaja yang terpapar pada tingkat kekerasan keluarga yang lebih tinggi. Wolf dan Temple (2018) menemukan bahwa pelajar laki-laki dan perempuan melaporkan frekuensi penggunaan alkohol pada 30 hari. Hasil menunjukkan bahwa mereka yang menjadi korban kekerasan dalam pacaran secara fisik dan verbal dalam 12 bulan terakhir melaporkan hal ini berhubungan dengan penggunaan alkohol.

\section{KESIMPULAN}

Berdasarkan hasil penelitian didapatkan gambaran faktor internal pacar dengan kekerasan dalam pacaran:

1. Gambaran kekerasan dalam pacaran didapati bahwa sebagian besar responden $(90.9 \%)$ tidak pernah mengalami Kekerasan dalam pacaran

2. Gambaran kategori usia pacar dari responden menunjukkan sebagian besar responden $(52.5 \%)$ berada di usia lebih tua 2 tahun dari responden.

3. Gambaran faktor internal pacar (penggunaan alkohol) menunjukkan bahwa sebagian besar pacar responden (84.8\%) tidak pernah minum alkohol.
4. Tidak ada hubungan faktor internal pacar jika ditinjau dari usia dengan nilai $\mathrm{p}=$ $0.145<0.05$.

5. Ada hubungan positif yang sangat signifikan faktor internal pacar jika ditinjau dari penggunaan alkohol dengan kekerasan dalam pacaran dengan nilai $\mathrm{p}=0.00$ serta nilai korelasi yang moderat (0.37).

\section{REKOMENDASI}

Berdasarkan hasil penelitian, pembahasan dan kesimpulan maka diajukan saran sebagai bahan pertimbangan:

1. Kepada masyarakat khususnya remaja perempuan karena didapati masih ada yang mengalami kekerasan dalam berpacaran maka untuk itu dapat berhatihati memilih teman laki-laki (pacar) dalam bergaul, khususnya yang tidak mengkonsumsi alkohol agar tidak mengalami kejadian yang buruk atau menyakitkan dalam berpacaran,

2. Bagi praktisi kesehatan dapat memberikan penyuluhan serta memperhatikan dan mengkaji lebih lanjut jika terjadi tanda-tanda kekerasan kepada remaja perempuan.

3. Bagian institusi pendidikan untuk dapat menjadi referensi pembelajaran tentang maternitas yang berhubungan dengankesehatan perempuan khususnya dalam $\mathrm{p}$

4. Kepada lembaga-lembaga yang bekerja untuk kepentingan perempuan untuk dapat memberikan penyuluhan di Sekolah ataupun tingkat Universitas serta dapat memberikan konsultasi pada remaja perempuan baik yang belum mengalami ataupun yang sudah menagalami berbagai bentuk kekerasan dalam pacaran

5. Bagi penelitian selanjutnya, dapat meneliti pada populasi dan sampel yang lebih besar untuk mendapatkan keakuratan data, serta dapat meneliti faktor lain seperti lamanya hubungan pacaran dengan kejadian kekerasan dalam pacaran. 


\section{Daftar Pustaka}

Alkitab.(2011) Lembaga Alkitab Indonesia: Jakarta

Anantri, K.M. (2015) Analisis factorfaktor yang mempengaruhi remaja putri terhadap perilaku kekerasan dalam pacaran di SMA " $X$ " Kota Semarang. Jurnal kesehatan masyarakat. Vol.3. No.3. April. (ISSN: 2356-3346) http://ejournals1.undip.ac.id/index.php/jkm

Ariestina, D. (2009). Kekerasan dalam pacaran pada siswi SMA di Jakarta. Jurnal Kesehatan Masyarakat Nasional. Vol. 3. No. 4. February

Brem, M.J., Florimbio, A.R., Grigorian, H., Elmquist, J., Clevenger, C.W., \& Stuart, G.L. (2018). CollegeBased Dating Violence Prevention Strategies. Chapter 16. Department of Psychology, University of Tennessee, Knoxville, TN: United States. DOI: https://doi.org/10.1016/B978-0-12811797-2.00018-9.

Darman, F. (2006). Mengenal jenis dan efek buruk narkoba. Visimedia: Tangerang.

Diaz, F.J.R., Herrero, J., Franco, L.R., Molleda, C.B., Quesada, S.G.P. \& Perez, B (2017) Validation of Dating Violence Questionnarie-R (DVQ-R). International Journal of Clinical and Health Psychology. 17, 77-84.

Espelage, D.I., Davis. J.P., Basile, K.C., Rostad, W.L., \& Leemis, R.W. (2018). Alcohol, prescription drug misuse, sexual violence and dating violence among high school youth. Journal of adolescent health. 00. 17
Hasan, N. (2013). Kekerasan dalam pacaran. Website: https://www.jurnalperempuan.org/ kekerasan-dalam-pacaran.html. Diakses tanggal 26 Agustus 2019.

International Encyclopedia of Public Health, 2nd edition, Volume 7 http://dx.doi.org/10.1016/B978-012-803678-5.00484-7

Jaffe, P., Fairhairn, J., \& Sapardanis, K.Youth (2018) Dating Violence and Homicide dolescent Dating Violence. DOI: https://doi.org/10.1016/B978-0-12811797-2.00008-6

Javdani, S., Sadeh, N., White, H.I., Emerson, E., Houck, C., Brown, L.K., (2019). Contextualizing pubertal development: The combination of sexual partners' age and girls' pubertal development confers risk for externalizing but not internalizing symptoms among girls in therapeutic day schools. Journal of Adolescence. 71. 84-90.

Kementerian Pemberdayaan Perempuan dan Perlindungan Anak RI (2018) web site:

(2018file:///Users/ivanna/Documen ts/Penelitian/Penelitian\%202019/da ta\%20ref\%20violence\%20/KEME NTRIAN\%20PEMBERDAYAAN $\%$ 20PEREMPUAN\%20DAN\%20P ERLINDUNGAN\%20ANAK.web archive

Komnas Perempuan (2018) . Catatan Kekerasan Terhadap Perempuan Tahun Website:

2017https://www.komnasperempua n.go.id/file/pdf_file/2018/Publikasi /Catatan\%20Tahunan\%20Kekerasa n\%20Terhadap\%20Perempuan $\% 20$ 2018 
Mari, N. B.V., Coyle, K.K., Gomez, C.A., Carvajal, S.C., \& KIRBY, D.B. (2000) Older Boyfriends and Girlfriends Increase Risk of Sexual Initiation in Young Adolescents. Journal of Adolescent Health. 27:409-418.

Martins, C., Gouveia, A., Chaves, M., Lourenco, R., Marques, S \& Santos, T. (2014). Dating Violence and Nursing Student Well-being. Aten Primaria.46 (Espec Cong 1). 129-134.

Martinus, A. (2018). Kekerasan Terhadap perempuan dan anak Sulut Meningkat. Website https://manado.tribunnews.com/20 18/12/03/kasus-kekerasanterhadap-perempuan-dan-anaksulut-meningkat

Nurherwati (2018) https://www.jurnalperempuan.org/ warta-feminis/sri-nurherwatikekerasan-dalam-pacaran-dapatberlanjut-padakdrtmengungkapkan

Reyes, H., Foshee, V., Bauer, D., \& Ennet, S.T. (2014). Heavy Alcohol Use and Dating Violence Perpetration During Adolescence: Family, Peer and Neighborhood Violence as Moderators. Prev.sci. 13. (4). 340349.

Rosdiana (2018). Cegah penggunaan narkotika melalui promosi kesehatan. CV. Kaaffah learning center: Sulawesi Selatan.

Rutherford, A. (2017).

Violence/intentional injuries Epidemiology and review.

Seifert, K. (2012). Youth violence: theory prevention, and intervention. New
York: Springer Publishing

Young, A.M., \& Arcy, H (2005) Older boyfriends of adolescent girls: the cause or a sign of the problem?. Journal of Adolescent Health. 36. 410-419.

White, E.G. (2013) Amanat kepada orang muda, IPH : Bandung

Wolf dan temple (2018) adolescent dating violence, theory, research and prevention. London; Elsevier 